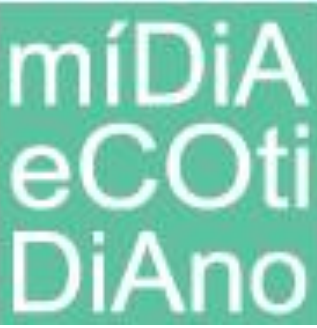

Revista Eletrônica do Programa de Pós-Graduação em Mídia e Cotidiano

Artigos Dossiê Comunicação e Cidadania

Número 5. Dezembro 2014

(C) 2014 by UFF

\title{
POSICIONAMENTO DISCURSIVO, VIOLÊNCIA E CIDADANIA: \\ A CONSTRUÇÃO DO "CASO NEW HIT" NO PORTAL \\ DE NOTÍCIAS G1 BAHIA
}

\section{Discursive positioning, violence and citizenship: the construction of the "New Hit" case in G1 News Portal Bahia}

\author{
Giovandro Marcus FERREIRA ${ }^{1}$; Tâmara Caroline Almeida TERSO²
}

Resumo: O presente artigo tem como objetivo analisar o discurso sobre a violência sexual tendo como corpus a cobertura do "caso New Hit" realizada pelo portal de notícias G1 Bahia. Inicialmente, serão abordados alguns conceitos sobre violência sexual e, especificamente, a violência sexual no Brasil. Em seguida, uma breve apresentação de alguns conceitos centrais da análise dos discursos e, enfim, uma análise dos títulos das matérias do webjornal referente ao "caso New Hit". Este estudo sobre a cobertura do acontecimento que consistiu em um estupro coletivo cometido por nove integrantes de uma banda de pagode baiana, fazendo vítima duas adolescentes no interior do estado, faz parte das atividades de monitoramento do CCDC - Centro de Comunicação, Democracia e Cidadania - da UFBA, que é utilizado para mobilização junto à sociedade civil e às autoridades públicas.

Palavras-chave: Mulheres, Violência, Posicionamento Discursivo, Discurso, Web.

Abstract: This article analyses the discourse on sexual violence used by the G1 News Portal (Bahia) with specific reference to a case of gang rape. The 'New Hit' case, as it came to be known in the Brazilian Press, consisted of a gang rape committed by nine members of a musical band in Bahia against two teenage victims in Bahia. Some notions about sexual violence and - more specifically - sexual violence in Brazil are presented and discussed, followed by a brief presentation of central concepts of discourse analysis, as a preliminary step to the subsequent analysis of the titles of the copy material relating to the "New Hit" case, as published by G1 News Portal. This study is part of the monitoring activities of the CCDC - Centre for Communication, Democracy and Citizenship (Universidade Federal da Bahia), a media observatory which aims at the mobilization of civil society and public authorities

\footnotetext{
${ }^{1}$ Professor Associado na Faculdade de Comunicação da UFBA - Universidade Federal da Bahia. Doutor em Ciências da Informação pela Universidade Paris 2 (Panthéon-Assas). Coordenador do CCDC - Centro de Comunicação, Democracia e Cidadania. E-mail: giovandro.ferreira@gmail.com

2 Jornalista recém-formada pela Faculdade de Comunicação da UFBA. Pesquisadora do Centro de Estudos e Pesquisa em Análise do Discurso. E-mail: tamaraterso@gmail.com
} 


\section{míDiA

Keywords: Women, Violence, Discursive Positioning, Discourse, Web.

\section{Introdução}

O "Caso New Hit" ocorreu na madrugada do dia 26 de agosto de 2012, quando integrantes da banda de pagode New Hit - nove músicos e um policial militar - foram acusados por duas jovens de 16 anos pelo crime de estupro após apresentação da banda na cidade de Rui Barbosa/ BA. A acusação do crime em poucas horas tornou-se noticia. Atribuímos a grande repercussão do acontecimento ao sucesso e perfil da banda (jovens da classe média, já envolvidos em outros fatos polêmicos); a idade das vítimas (menores de 18 anos); o crime de estupro; e a mobilização social provocada principalmente pela organização feminista Marcha Mundial das Mulheres ${ }^{3}$.

A banda New Hit foi formada em 2011, composta pelo vocalista Eduardo Martins e mais oito integrantes. Seu repertório de pagodes com letras de duplo sentido e suas apresentações com coreografias de forte apelo sexual renderam ao grupo a fama de polêmica. Em ensaios ocorridos no mesmo ano do caso em questão, a banda já havia se envolvido em escândalos, porque os dançarinos simulavam atos sexuais no palco com suas fãs em boates de Salvador.

Para uma banda recém-formada a New Hit fazia um sucesso considerável, com apresentações fixas em casas de show de Salvador, agendas pelo país e quatro fã clubes/ FC "oficiais" na rede de relacionamento Facebook ${ }^{4}$, totalizando cerca de 35 mil seguidores. Seu público alvo era constituído por jovens entre 12 a 29 anos, mulheres de classe média e baixa, que durante o caso organizaram-se algumas vezes para defender a banda com atos de rua.

Após a acusação, os integrantes da banda New Hit e o policial envolvido no caso foram presos, permanecendo 38 dias detidos. Através de habeas corpus foram liberados

\footnotetext{
${ }^{3}$ A Marcha Mundial de Mulheres nasceu em 2000 como ação internacional contra a pobreza e a violência contra mulher. Inspirada em outra ação feminista ocorrida cinco anos antes no Quebec/ Canadá, este ato foi chamado de "2000 razões para marchar contra a pobreza e a violência sexista", que ao final organizou um documento para a ONU com 17 pontos de reivindicação e assinado por mais de cinco milhões de mulheres.

${ }^{4}$ FC New Hit Oficial: 22.433 likes; Fã clube New Hit oficial: 82 likes; Isso é o que Dimdolê? Isso é New Hit: 9.632 likes; Quarteto Fantástico: 3.293 likes
} 


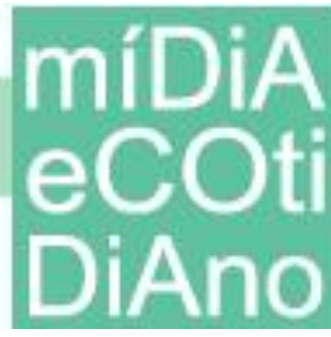

e voltaram a cumprir agendas de show, o que desde o início despertou mobilizações contra e a favor da banda.

As manifestações contra a banda e em favor das vítimas têm destaque pelo grande volume de ações e seu potencial mobilizador. Desde que a MMM - Marcha Mundial das Mulheres - passou a acompanhar o caso - de forma sistemática -, a repercussão em nível nacional do crime foi impulsionada e culminou em atos coordenados em todo país. Destacamos aqui as ações de acompanhamento jurídico, acampamentos e vigílias públicas no fórum no qual o caso tramitou, formações políticas na cidade em que ocorreu o crime, protestos nos shows da banda, entre outros. Além de chamar atenção para o caso, a MMM aprofundou o debate sobre a violência sexual, denunciando a rede de relações subjetivas que servem para deixar estes e outros casos inalterados.

No período de tramitação do caso as adolescentes foram incluídas em um programa de proteção de vítimas e testemunhas do Governo do estado, mudando de cidade e alterando suas identidades. Em 11 de setembro de 2013, a banda chegou ao fim por uma declaração da sua produtora - Sacra - que alegou ter prejuízos assessorando uma banda acusada de estupro. O último julgamento do caso ocorreu entre os dias 03 e 05 de setembro de 2013 e até o encerramento desta pesquisa seu resultado não tinha sido divulgado.

\section{O fenômeno da violência sexual no Brasil}

A violência sexual no Brasil é alarmante e, de acordo com dados do Fórum Brasileiro de Segurança Pública ${ }^{5}$, em 2012 o crime de estupro foi maior que os homicídios dolosos. Ao todo foram 50.617 casos, equivalente a 26,1 estupros para cada 100/mil habitantes. Os maiores índices ocorrem na região Norte do país e estima-se que estes números foram revelados devido a mudanças ocorrida no Código Penal em 2009, quando os atos libidinosos e as relações para além da conjunção carnal tornaram-se

\footnotetext{
${ }^{5}$ http://www2.forumseguranca.org.br/novo/ . Acessado em 25/11/2013.
} 


\section{míDiA

crimes de estupro, aumentando a pressão social por causa da revelação dos índices do crime, antes disfarçado pela ambiguidade da lei.

O crime de estupro no Brasil foi reconhecido em 1940 com a aprovação do Código Penal. Este crime trata da violência sexual e está contido no título VI - Artigo 213, na parte especial do Código Penal - referente aos crimes sexuais. Em 2009, o crime passou por reformulações: o título no qual estava contido passou a se chamar "Crimes contra a dignidade sexual", e o texto do artigo descreve o crime como conduta de "constranger alguém, mediante violência ou grave ameaça, a ter conjunção carnal ou a praticar ou permitir que com ele se pratique outro ato libidinoso". A mudança passou a incluir homens e mulheres como possíveis vítimas. $\mathrm{O}$ crime comum atinge pessoas maiores de 14 anos, e nas vitimas abaixo desta idade hoje vigora o artigo, 217-A, sob o nome de "crime de estupro de vulneráveis", com penas mais graves.

Por tratar de caso envolvendo duas adolescentes de 16 anos, vale lembrar que, além do Código Penal, o "caso New Hit" se enquadra no crime de abuso sexual de adolescentes, previsto no Estatuto da Criança e do Adolescente/ ECA. Criado em 1990 pela Lei Federal $\mathrm{n}^{\circ}$ 8.069, o ECA, como também é conhecido, constitui-se em um conjunto de normas jurídicas e direitos legais que protege crianças e adolescentes de 0 a 18 anos. Este marco legal foi criado para responder demandas internacionais referentes à Declaração Universal do Direito da Criança e documentos complementares da ONU: "Regras Beijing"; Regras Mínimas das Nações Unidas para a Elaboração de Medidas não Privativas de Liberdade (Regras de Tóquio); "Diretrizes de Riad".

No ECA, o abuso sexual de crianças e adolescentes, além da prostituição, é crime previsto nos artigos 18 e 244-A. Foi a partir desta legislação e da aprovação da lei 9.970/00, que prevê o dia 18 de maio como Dia Nacional de Luta contra o Abuso e a Exploração Sexual que as denuncias aumentaram a ponto de ser instalado, em 2003 pelo Governo Federal, a Comissão Intersetorial de Enfrentamento à Violência Sexual Contra Crianças e Adolescentes. Esta comissão coordenada pela Secretaria de Direitos Humanos, em parceria com o Fundo das Nações Unidas para as Crianças, mapeou o fenômeno da violência sexual contra crianças e adolescentes em todo território 


\section{míDiA

brasileiro. Os dados foram alarmantes principalmente no Nordeste do país, que despontou com $31 \%$ dos casos.

Para a recém-fundada Secretaria de Política para as Mulheres, ligada à Presidência da República, a violência sexual é uma das mais cruéis e pode ser considerada um problema de saúde pública, por sua incidência alarmante e os danos incomensuráveis causados à saúde física e mental das vítimas, que precisam imediatamente de suporte do Estado.

Para debater os altos índices de crimes contra as mulheres, recorremos ao conceito de Feminicídio, usado pela primeira vez pela socióloga sul-africana Diana Russell, em 1976, no Tribunal Internacional de Crimes contra as Mulheres, organizado em Bruxelas por Simone de Beauvoir ${ }^{6}$. A socióloga usou o termo para denominar um crime cometido de forma violenta por homens contra as mulheres, pelo fato de serem mulheres, ou seja, um crime contra o gênero feminino. Anos mais tarde, Russell (2006) denominou o Feminicídio como assassinato motivado por ódio, desprezo e sentido de propriedade do corpo das mulheres.

Marcela Lagarde (2006) acrescenta ao conceito de Russell o aspecto da impunidade da sociedade e a desigualdade de gênero produzida pelo patriarcado, e tipifica o crime como "crime de Estado". Lagarde ainda complementa que o crime se manifesta em todos os momentos, em tempo de guerras ou de paz.

A partir de um estudo realizado na cidade de Juárez, no México, a socióloga Julia Monárrez (2010) classificou o feminicídio em três categorias: feminicídio íntimo, que subdividi-se em infantil e familiar; feminicídio sexual sistêmico, que subdividi-se em organizado e desorganizado; e feminicídio por ocupações estigmatizadas. Com estas definições, o feminicídio adquire vertentes sócio-territoriais, porém sua ideia nuclear permanece como um fenômeno da violência contra as mulheres, provocada por homens, através da construção social inferiorizante do gênero feminino, que muitas vertentes da teoria feminista vão associar à organização do patriarcado. O conceito de patriarcado

6 Simone Lucie-Ernestine-Marie Bertrand de Beauvoir, mais conhecida como Simone de Beauvoir (Paris, 9 de janeiro de $1908-\quad$ Paris, 14 de abril de 1986), foi uma escritora, filósofa existencialista e feminista francesa. Fonte: http://pt.wikipedia.org/wiki/Simone de Beauvoir . Acessado em 10/07/2014. 


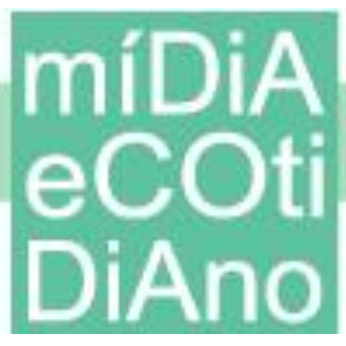

PPGMC

não é recente; muitos teóricos conceituam o termo como sociedades tradicionais que se organizam centradas na figura de um patriarca - o homem. A partir da década de 60, teóricas feministas recorreram a este conceito para denominar a dominação masculina sobre as mulheres, do ponto de vista universal a partir da sua amplitude e específico em seu método. Neste período, muitas estudiosas vão dizer que o patriarcado é uma organização social que sistematicamente beneficia o homem, material e simbolicamente, em detrimento da mulher. O homem exerce o poder sobre todas as coisas e coloca neste espectro as mulheres. Nos cadernos de texto da MMM, o patriarcado aparece como organizador das relações sociais no qual a figura do homem orienta a conduta social. Acreditando na crença de inferioridade da mulher, o sistema patriarcal a transforma em posse, como extensão de posse dos bens materiais.

É importante ressaltar que o conceito apresenta divergências e limites. A historiadora Joan Scott (1995) chama atenção para o movimento de engessamento das causas de dominação das mulheres advindo da utilização totalizante do patriarcado para analisar fenômenos de gênero. Piscitelli (2002) acredita que essa aplicação se tornou uma noção essencializante da opressão de gênero, deixando de dar conta de outras variantes e tornando-se determinista do ponto de vista de conceber a opressão sobre as mulheres apenas em uma lógica ocidental. O conceito em geral não leva em consideração sistemas nativos de moralidade e concepções nativas de poder, revelados a partir de uma série de estudos antropológicos nos anos de 1980. Contudo, ainda hoje o patriarcado é amplamente aplicado para análises da opressão que as mulheres sofrem na sociedade e se torna relevante em nossa pesquisa, principalmente para debater as fronteiras históricas/simbólicas e materiais estabelecidas entre homens e mulheres. Como exemplo, apontamos a presença dominante do homem nos espaços públicos e das mulheres nos ambientes privados da sociedade. Estes elementos justificam na maioria dos casos a violência sexual, e podemos identificá-los no caso New Hit através do discurso reforçado pelos meios de comunicação, como veremos na análise, questionando a presença das mulheres em determinados locais (shows, boates) e em determinados horários (noturnos). 


\title{
míDiA

Aprofundando o estudo da violência sexual contra as mulheres, avaliamos que ela está entre algumas formas de violência de gênero (violência doméstica, intrafamiliar, etc.), termo mais amplo que designa um conjunto de dispositivos violentos de dominação do homem sob as mulheres, crianças e adolescentes, como afirma a socióloga Heleieth Saffioti (2002).

\begin{abstract}
Violência de gênero é o conceito mais amplo, abrangendo vítimas como mulheres, crianças e adolescentes de ambos os sexos. No exercício da função patriarcal, os homens detêm o poder de determinar a conduta das categorias sociais nomeadas, recebendo autorização ou, pelo menos, tolerância da sociedade para punir o que se lhes apresenta como desvio. Ainda que não haja nenhuma tentativa, por parte das vítimas potenciais, de trilhar caminhos diversos do prescrito pelas normas sociais, a execução do projeto de dominação/exploração da categoria social homens exige que sua capacidade de mando seja auxiliada pela violência. (SAFFIOTI, 2002, p. 02).
\end{abstract}

Para Brownmillwe (1975) é possível ainda falar na "cultura do estupro", que, por meio da violência sexual, pune as mulheres que não compartilham das normas impostas pelo patriarcado. Assim o estupro caracteriza-se não por um crime relacionado com sexo ou desejo sexual, mas com a revelação das relações de poder que deixam as mulheres em estado permanente de medo. A "cultura do estupro" abre margem para o surgimento dos estupros corretivos e coletivos que acometem mulheres que exercem sua sexualidade livre ou que se rebelam contra a organização patriarcal estabelecida. A violência neste caso age, permitidamente como ação "pedagógica", para barrar ações avaliadas como erradas. Quando falamos em permissão atentamos para o fato de que nos casos de estupro em geral é comum ouvir opiniões que justifiquem o fato de a violência ter acontecido por causa da "roupa que a mulher usava no momento da violência", "lugares por onde andava", "seu comportamento diante dos homens", entre outros. Assim a violência naturaliza-se, reforçada em todas as esferas sociais, coadunando com o sistema patriarcal. Saffioti observa que é importante analisar a violência de gênero no conjunto das relações sociais. Para alguns autores, como Azevedo e Guerra (1989), este fenômeno da violência acontece no âmbito interpessoal, porém para Saffioti é um equívoco separar relações interpessoais das relações estruturais de classe, sob pena de empobrecer a reflexão dos impactos da violência na 


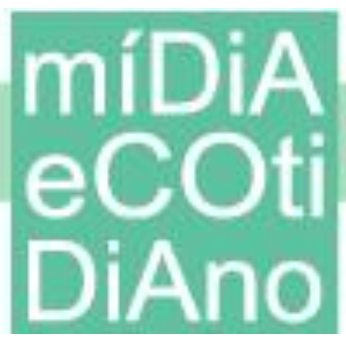

relação de mundo. Para ela é preciso pensar em um tipo de conhecimento que veja a sociedade por inteiro, com suas contradições, desigualdades e iniquidades.

\section{O portal de notícias G1 Bahia e seu posicionamento discursivo no "caso New} Hit" $^{\prime \prime}$

O portal G1 - Globo Comunicação e Participação Social S/A, é um canal brasileiro de notícias na web mantido pela Central Globo de Jornalismo, das organizações Globo ${ }^{7}$. Criada em 2006, o portal gera conteúdo jornalísticos para a web com três redações fixas pelo país (Rio de Janeiro, São Paulo e Brasília), também retransmitindo notícias dos veículos midiáticos da Rede Globo. Em 2010 o G1 incorporou suas afiliadas como categorias separadas por regiões geográficas no site; na Bahia, a Rede Bahia de Televisão ficou responsável pelo gerenciamento desta ferramenta. Assim, o G1 Bahia foi lançado e passou a ter uma redação específica, além de retransmitir as matérias produzidas pela TVs locais, do G1 nacional e outros conteúdos Globo.

O portal G1 é considerado pela ALEXA $^{8}$ o sexto portal mais acessado do Brasil, além de ser gerenciado pelo maior conglomerado no setor de mídia da América latina. O G1 acompanha a linha editorial dos formatos impressos e televisivos da Rede Globo, e a forte convergência de seus recursos multimidiáticos pode ser uma explicação aos números de acesso apresentados acima. Isso porque, em webjornalismo, a coexistência da multimidialidade, interatividade e hipertexualidade dinamiza o acesso às matérias através da possibilidade de leituras rápidas, visualizações de vídeos curtos e informativos e muito conteúdo compacto em um só tempo.

Neste estudo escolhemos analisar o caso New Hit através do posicionamento discursivo apontado pelos títulos nas coberturas jornalísticas, que, para Verón (2004), é um operador que tem duas dimensões fundamentais no discurso: a primeira,

\footnotetext{
7 Maior conglomerado de empresas no setor de mídia no Brasil. Fonte: http://pt.wikipedia.org/wiki/Organiza\%C3\%A7\%C3\%B5es_Globo. Acessado em 02/12/2013.

${ }^{8}$ Alexa Internet Inc. é um serviço de Internet pertencente à Amazon que mede quantos usuários de Internet visitam um sítio da web. Fonte: http://pt.wikipedia.org/wiki/Alexa_Internet. Acessado em 02/12/2013.
} 


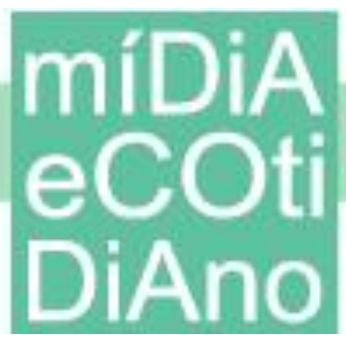

metalinguística que qualifica e nomeia, e a segunda, a dimensão referencial que diz "algo" sobre o discurso. Assim, também tomando como base as características essenciais do discurso resultantes de uma análise apurada e para além da linguística, Maingueneau (2002) propõe as seguintes especificidades: (1) O discurso é organizado para além da frase; (2) orientado; (3) tem forma de ação; (04) é interativo; (4) contextualizado; (5) assumido por um sujeito; (6) regido por normas; e (7) considerado no bojo do interdiscurso. Estas características apresentam o discurso como um conteúdo complexo que não pode ser analisado individualmente, que se dirige a algum lugar desenvolvendo-se no tempo de forma linear e praticando uma ação sobre o outro constituído em atos. Este conceito nos mostra que a pratica do discurso está impregnada de composições para a produção de sentido, e é basicamente resultante da combinação de "o que se fala/escreve", com a maneira pela qual se "fala/escreve", condição de entrecruzamento das condições extradiscursivas com as realizações intradiscursivas, implicadas nas formações socioculturais das formas e conteúdos de visão do mundo (CHARAUDEAU, 2009).

O conceito de enunciação se coloca no patamar da forma, tentando fugir do aspecto conteudístico do discurso. Benveniste (1989, p.80) dizia de forma abreviada que "a enunciação é essa colocação em funcionamento da língua por um ato individual de utilização" ou de maneira próxima, segundo Jean Dubois (1969), referindo-se à enunciação como o impacto do sujeito no interior do seu próprio discurso. A linguística oferece ao conceito de enunciação as três categorias que estão sujeitas à instabilidade no discurso: as categorias de pessoa, de espaço e de tempo. Na análise do(s) discurso(s) no interior das pesquisas de comunicação mediática, tais categorias vão ser aplicadas em diferentes matérias significantes, também não-verbais, sobretudo a partir de orientações ofertadas por Roland Barthes no seu último trabalho, dedicado ao estudo da fotografia (BARTHES, 1980).

Buscamos trabalhar com a noção de dispositivo de enunciação para operacionalizar a instabilidade e, por conseguinte, o posicionamento discursivo. Três instâncias se abrem, metodologicamente, tendo em vista o funcionamento enunciativo: o lugar daquele que fala (Enunciador), o lugar a quem é endereçado o discurso 


\section{míDiA

(CoEnunciador) e o tipo de relação que se estabelece. Pelas tramas da enunciação, podese caracterizar estas instâncias que articulam a forma e sentido do discurso.

O título representa uma matéria significante muito importante na construção do sentido num portal, pois ele é a última "peça" construída da matéria ou notícia. O título é uma interpretação oferecida pelo suporte imprensa acerca da notícia, uma espécie de chave de leitura, que divide com as ilustrações a primeira leitura ou o sobrevôo do início de leitura.

O título informativo vive sob o império do tempo presente. A escolha deste tempo representa, antes de tudo, um posicionamento dos sujeitos discursivos. O tempo presente é um tempo do mundo comentado, que cria uma tensão entre os sujeitos implicados (WEINRICH, 1973). O título pode, igualmente, ser um discurso direto, geralmente entre aspas, ou um discurso indireto.

O discurso indireto oferece sobretudo o discurso daquele que reporta (portal). Há uma subordinação do discurso original que, por sua vez, não tem autonomia em relação ao discurso do suporte informativo. O discurso indireto serve especialmente para impor a voz do jornal. Em contrapartida, o discurso direto busca como efeito de sentido a apreensão do discurso da fonte em "estado bruto", uma aproximação do jornal com o fato ocorrido, com o "real".

O título pode também provocar mudança de sentido pela simetria ou não entre os sujeitos discursivos. Pela relação entre eles, pode-se ter uma construção de distância ou de cumplicidade. Uma relação pedagógica (assimétrica, pois o jornal se coloca no papel de ensinar) ou então, tentar se apresentar numa posição de distância supostamente “objetiva". Um recurso na construção do título pedagógica pode ser pela escolha do verbo (aconselha, indica etc), como também fazendo apelo, entre outras, à utilização de número, construindo um efeito de sentido de possuir um saber com exatidão. Logo, um mesmo conteúdo pode adquirir diferentes formas, consequentemente provocando mudança no sentido das matérias significantes, no caso específico, do título.

O domínio da análise do discurso propõe um estudo interdisciplinar do texto, buscando examinar criticamente os processos de produção, circulação e consumo dos sentidos vinculados aos produtos culturais, tomando o contexto como condição social 


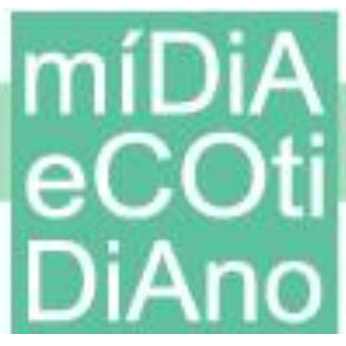

PPGMC

desta produção (Verón, 1978). Estes elementos justificam por si só analisar a abordagem do contexto da violência sexual, aliada a outras características do meio no qual o portal G1 Bahia está inserido, para chegar ao posicionamento discursivo do "caso New Hit”.

Em um momento de comunicação as condições de troca são preponderantes para a efetivação dos interesses e lugares sociais. Segundo Charaudeau (2009), é preciso estabelecer um quadro de referências no qual a comunicação tenha parâmetros para realizar-se, ao passo que o individuo também possa recorrer a essas "regras" para iniciar um processo comunicativo. Assim o modo de estabelecimento destas referências acontece pela apreensão, legitimação e regulação das práticas sociais pelos indivíduos no patamar da comunidade, e pelo discurso de representação que justifica e valoriza essas práticas. É então, a partir deste processo, que se cria as formas linguageiras que constituem a comunicação em sociedade e seus respectivos posicionamentos.

O autor explica que, para que a comunicação aconteça sem prejuízo, é preciso que tanto o locutor quanto o destinatário estejam cientes destas restrições, as reconheçam e consigam operar nelas. A este reconhecimento chamamos de contrato de comunicação midiática, que se impõe pelos aspectos próprios à situação de troca (dimensão externa) e os aspectos discursivos decorrentes (dimensão interna). A dimensão externa é estabelecida por situações recorrentes de troca e por uma regularidade comportamental que se mantém estável por um longo período de tempo, desse modo agregando valor aos atos de fala. A enunciação é um elemento importante para os reconhecimentos destes atos.

Maingueneau, no entanto, aponta distanciamento e cuidado com alguns pressupostos, para que, segundo ele, possamos acolher com mais eficácia este conceito na análise do discurso. $\mathrm{O}$ autor atenta para que a enunciação não seja entendida como apropriação por um indivíduo, nem repouse em um único enunciador, pois a interação é preponderante, e o indivíduo que fala não necessariamente se encarrega desta. Ele afirma que a maior contribuição da enunciação é expor o caráter reflexivo da atividade linguística. A enunciação "é o pivô da relação entre a língua e o mundo: ela permite 


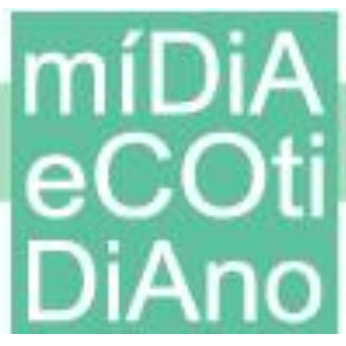

PPGMC

representar no enunciado os fatos, mas ela constitui em si um fato, um acontecimento único, definido no tempo e no espaço”. (MAINGUENEAU, 1987, pg. 193).

Podemos elencar quatro categorias que se referem a condições de enunciação empregadas na produção do discurso: condição de identidade (que determina os sujeitos da comunição pelas características de status social, econômico e cultural, pertinente ao ato de fala inscrito); condição de finalidade (que indica o objetivo da fala através de visadas prescritivas, informativas, iniciativas e do páthos); condição de propósito (que se vincula a um domínio do saber partilhado pelo destinatário); e a condição de dispositivo (que identifica o local onde se dará a fala, uma espécie de quadro topológico da troca).

A tomada de posição diante dos atos de comunicação requer a construção de espaços de comportamento em linguagem que se dividem em três categorias: espaço de locução (onde o indivíduo falante disputa seu lugar na fala, organizando também o lugar de seu destinatário); espaço de relação (lugar onde o indivíduo que fala estabelece a relação de força ou aliança com o destinatário); e o espaço de tematização (local de organização do saber, seja inerente ao contrato ou adicionado através dos participantes em troca linguageira) (MAINGUENEAU, 2002). No entanto, Charaudeau (2009) ressalta que mesmo com a existência do contrato de comunicação é possível estabelecer autonomias se o indivíduo que fala decide estrategicamente optar por um ato de linguagem que expresse o seu próprio projeto de fala. Desse modo, podemos estabelecer que todo ato de linguagem é libertário, sendo esta liberdade sempre controlada e limitada.

Para analisar o caso New Hit organizamos um corpus de matérias publicadas no portal G1 Bahia na faixa temporal de 26 de agosto de 2012 a 19 de setembro de 2013. Estas datas são referentes ao dia do crime (26) e seu último julgamento (19), totalizando uma média de treze meses, em um processo de clipagem que somou 71 títulos vinculados ao tema. As palavras-chave utilizadas na busca dos títulos foram: New Hit, Estupro, Rui Barbosa, Feministas, Jovens e Mulheres. Os títulos foram analisados individualmente procurando destacar suas estratégias discursivas e combiná-las através dos posicionamentos discursivos. 


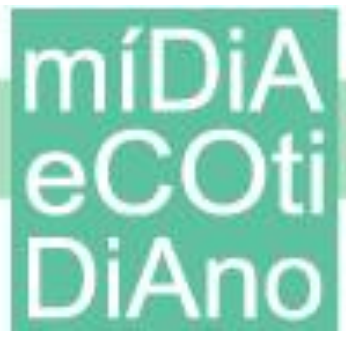

Notamos que para tratar dos episódios jurídicos no "caso New Hit", o G1 Bahia na maioria dos títulos assume a escolha de utilizar verbos no modo indicativo, no tempo presente (confirma, nega, aponta, acusam, pede etc). Assim, o veículo informa à recepção em que fase se encontra o caso, seguido de um subtítulo que descreve e explica a ação do título, com detalhes que dispensam a leitura completa da matéria. Um elemento complementa o outro, oferecendo um circuito interpretativo para a audiência através da relação informativa/explicativa da relação título e subtítulo, conforme quadro abaixo:

Quadro 01

(A) 31/08/2012 - Laudo que pode apontar confirmação de estupro de adolescentes será divulgado na próxima semana

(B) 03/09/2013 - 12h15 - Laudo confirma que meninas foram estupradas por integrantes de Banda. (Resultado de exames de corpo de delito foi divulgado nesta segunda-feira. Nove membros da banda de pagode New Hit estão detidos em presídio.)

(C) 04/09/2012 - Caso New Hit: exame vai identificar material genético encontrado na roupa das jovens

(D) $\mathbf{0 6 / 0 9 / 2 0 1 2}$ - 16h37 - Justiça nega habeas corpus de oito integrantes da banda de pagode. (Desembargador do tribunal da justiça negou o pedido nesta quinta (06). Outro pedido de habeas corpus de um dos membros, ainda não foi julgado.)

(E) 17/09/2012 - 19h55 - Jovens que acusam banda por estupro recebem proteção judicial. (Adolescentes fazem parte do programa de Proteção (PPCAAM). Elas foram levadas para Salvador para reinserção na sociedade.)

(F) 24/09/2012 - 16h45 - Laudo aponta sêmen em roupa de adolescentes, afirma a polícia na Bahia. (Jovens acusam integrantes da banda New Hit de estupro após show do grupo. 'pericia aponta grande quantidade de sêmen', diz coordenadora da polícia.)

(G) 25/09/2012 - Perícia confirma versão de adolescentes sobre estupro por 
músicos da New Hit

(H) 03/10/2012 - $12 \mathrm{~h} 17$ - Integrantes da New Hit e PM tem pedido de habeas corpus deferido (Pedido foi julgado pelo desembargador Lourival Almeida Trindade. De acordo com o diretor do complexo penitenciário, eles devem sair na quarta)

(I) 03/10/2012 - 15h35 - Após 38 dias, integrantes da banda de pagode New Hit são soltos na BA (Integrantes são suspeito de estupro e formação de quadrilha. Após habeas corpus, os nove jovens responderão o processo em liberdade)

(J) 05/10/2012 - Banda New Hit marca o primeiro show 24h após serem liberados da cadeia.

(K) 19/02/2013 - 19h28 - Promotora de justiça pede exame de DNA de integrantes da banda New Hit (Mariza Jansen fez apelo a juíza para ajudar a confirmação das provas. Audiência de instrução ocorre há 1 dia para apurar denuncia de estupro.

O veículo assume uma posição de porta-voz oficial do caso, com declarações que informam o leitor com agilidade sobre os posicionamentos da justiça, explorando a atualidade dos fatos. Os títulos (I) e (J) marcam com mais intensidade a busca do veículo pela legitimação vinda do discurso da atualidade, usando o numeral para exemplificar os dias em que os acusados passaram na prisão e quantidade de horas pósprisão para fazer o primeiro show. Nesta fase inicial da cobertura, o portal evita adjetivações, e seu efeito de sentido transita entre um portal que informa em "primeira mão" todas as decisões jurídicas e investiga, próximo à justiça, os passos dos acusados e vítimas e o próprio judiciário.

Um caso que nos chama atenção é a relação dos títulos (D) e (H). Os dois títulos e subtítulos tratam do pedido de habeas corpus requerido pelos acusados; (D) é referente à negação do primeiro pedido e $(\mathrm{H})$ trata da liberação do mesmo. Em ambos os casos é um determinado desembargador que julga os pedidos. Quando é negado, apenas o cargo do magistrado é citado, porém, quando o habeas corpus é aceito, nome e 


\section{míDiA

sobrenome do desembargador são registrados na enunciação, revelando sua identidade. Outra identidade revelada aparece no título (K), no qual a promotora que faz um pedido de exame de DNA é indicada com nome e sobrenome, no subtítulo da matéria.

É a partir de 20/02/2013, data em que o esperado resultado do primeiro julgamento do caso é adiado, que o posicionamento discursivo do portal tem mudanças significativas, tomando um direcionamento que expressa juízo de valor acentuado. Com o titulo "20/02/2013 - vídeo: Audiência de instrução do Caso New Hit é adiada para setembro", o portal utiliza uma declaração própria para tipificar o acontecimento como "um caso" oriundo de uma narrativa construída pelo próprio portal. Chamamos este recurso de estratégia discursiva de proximidade entre o enunciador (portal) e o leitor, onde um e outro partilham do mesmo conhecimento sobre "o caso". Anteriormente, o termo "Caso New Hit" havia sido registrado no título "04/09/2012 - Caso New Hit: exame vai identificar material genético encontrado na roupa das jovens", porém neste título o termo veio acompanhado do conectivo interdiscursivo dois-pontos. Este conectivo substituía as aspas, de modo que a fala/posicionamento não era do G1, mas uma fala externa. A partir deste episódio o que segue são conjuntos de enunciações expressando nitidamente um posicionamento em resposta às pressões sociais que reivindicam celeridade no julgamento do caso, assim como a mudança de tratamento da banda, conforme abaixo:

Quadro: 02

(A1) 01/04/2013 - 12h34 - Show de banda acusada de estupro ocorre sob protesto em Fortaleza (Grupo tentou impedir a realização do show da banda New Hit em Fortaleza. Banda é acusada de estupro na cidade de Ruy Barbosa, na Bahia)

(B1) 26/08/2013 - 05h54 - Caso New Hit completa um ano sem desfecho; adolescente deixa abrigo (Advogados de acusação e defesa acreditam que o caso está perto do fim. Audiência será realizada nos dias 03, 04 e 05 de setembro em Ruy Barbosa)

(C1)03/09/2013 - 19h27 - DNA de 06 dos 10 réus do caso new hit foi 
detectado, afirma promotoria (Laudo apresentado em audiência identifica sêmen na roupa das vítimas. Sessão foi suspensa a pedido da defesa que alegou insegurança).

Os títulos (A1) e (C1) identificam os acusados não só como "músicos", "vocalista" e "dançarinos" da banda New Hit, mas também como "banda acusada de estupro" e "réus". A mudança na forma de enunciar os acusados ocorre no mesmo momento em que o caso caminha para seu desfecho com grande probabilidade de confirmação do crime e prisão dos acusados. Neste momento, o portal decide tomar o posicionamento do lado da justiça, evidenciando traços de "coerência moral" do portal, que toma partido não dos "criminosos", mas da justiça, detentora de tratamento equânime.

Identificamos também as situações intermediárias na cobertura, e que tem relação com o tratamento dos protestos e das declarações de vitimas e acusados no caso. Veja abaixo:

Quadro: 03

(A2) 01/09/2012 - 21h58 - Grupos contrários se manifestam no caso da banda New Hit em Salvador (Manifestantes demonstram apoio ou repúdio ao grupo. Músicos são suspeitos de estuprar duas jovens no interior do estado).

(B2) 15/10/2012 - 15h08 - Mulheres protestam contra vocalista da New Hit em casa de veraneio na BA (Eduardo Martins está entre nove suspeitos de estuprar adolescentes. Manifestantes fazem parte da Marcha Mundial das Mulheres).

(C2) 19/02/2013 - Caso New Hit: militantes e policiais militares discutem na porta de fórum.

(D2) 27/03/2013 - 07h30 - Mulheres querem impedir show da banda New Hit em Fortaleza (banda new hit é acusada de estuprar duas adolescentes na Bahia. Integrantes da banda ficaram 38 dias presos).

(E2) 04/01/2013 - 14h38 - Delmirenses protestam contra show de banda acusada de estupro. (Integrantes da banda de pagode New Hit foram indiciados 


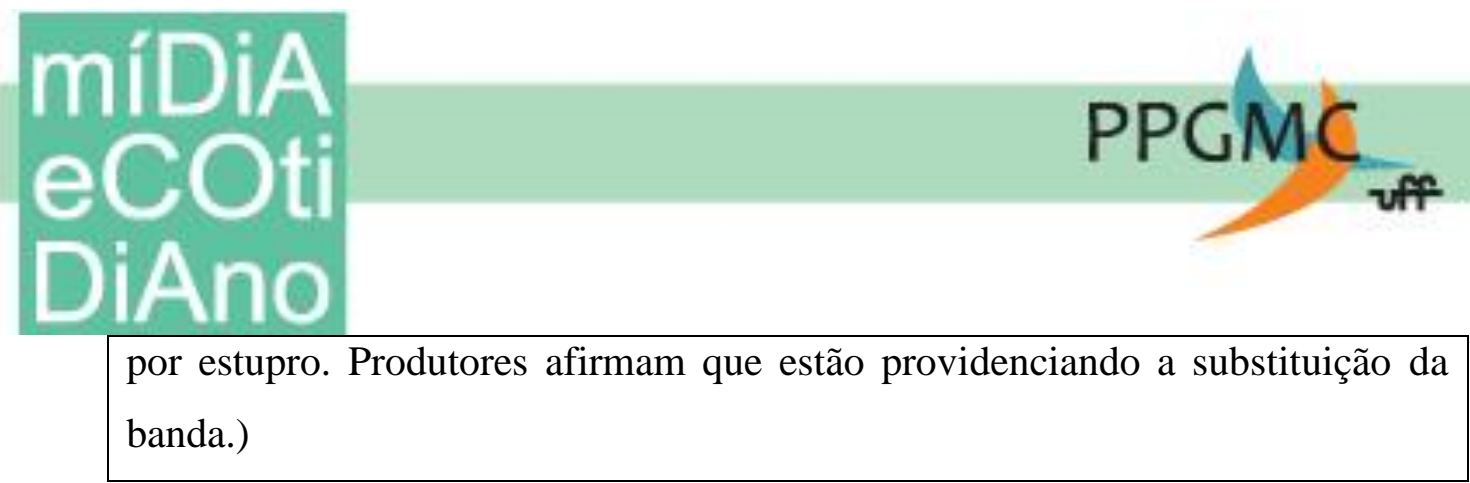

Nas enunciações acima, nenhum dos títulos que trata dos protestos ocorridos durante caso apontou com precisão a origem das/dos manifestantes, referenciando-os/as apenas pelos substantivos "mulheres" e "grupo", e pelos adjetivos "militante". Em apenas dois casos, foi registrada a origem dos protestos: exemplo (B2) e (E2), no qual o nome do movimento feminista é revelado "Marcha Mundial das Mulheres", assim como a origem territorial "Delmirenses".

Neste aspecto, observa-se que a estratégia discursiva provoca o efeito de sentido da imparcialidade do portal, pois ao se eximir de identificar os movimentos, sejam eles em defesa das vítimas ou dos acusados, o G1 permanece no polo informativo, sem promoção de nenhuma das partes. Porém observamos a contradição nas enunciações envolvendo os posicionamentos em primeira pessoa, nas quais o portal prioriza a apresentação das falas dos acusados em detrimento das vítimas. Veja abaixo:

Quadro: 04

(A3) 28/08/2012 - 18h45 - "Meu Filho tem índole", afirma mãe de músico suspeito de estupro na Bahia. (Vocalista e outros oito integrantes da banda estão presos desde o domingo. Eles e mais um policial militar, são suspeitos de estuprar 2 garotas na BA.)

(B3) 03/10/2012 - 17h04 - "Estamos livres e agora as verdades vão aparecer", diz vocalista da New Hit (Jovem conversou com o G1 após sair de presídio, a caminho de Salvador. Ele foi preso juntamente com oito integrantes, no dia 26 de agosto).

(C3) 04/10/2012 - 14h31 - "Não podemos ir às ruas que ouvimos piadinhas", diz cantor da New Hit (Nove integrantes são suspeitos de estuprarem duas adolescentes após show. Eles foram soltos do Complexo Penal de Feira de Santana na quarta-feira 03).

(D3) 20/02/2013 - 20h25 - Garotas que denunciam banda por estupro agradecem apoio em carta (mensagem escrita em folha rosa teve como 
assinatura 'vítimas de new hit'. Militantes contam que elas dizem que 'quase desistiram' de seguir o processo.)

No título (A3), a adjetivação "ter índole", através de um discurso direto, expresso pela mãe de um dos integrantes da banda New Hit, identifica um espaço aberto pelo portal para justificar o crime, através da qualidade de cunho moral do vocalista da banda de "ter índole". Em (B3) é a vez dos próprios integrantes terem espaço para falar sobre o caso. Em uma citação direta um deles afirma falar "a verdade" e buscar provas para ser inocentado. Além disso, no subtítulo o portal apresenta um discurso descontraído, de conversação com os acusados, em "Jovem conversou com o G1 após sair de presídio, a caminho de Salvador", suscitando o efeito de proximidade com o caso. Já em (C3) foi a vez de ceder espaço para as queixas da baixa popularidade e julgamento da banda pela opinião pública. Apenas em (D3) a declaração das vítimas tem espaço no portal, contudo a fala está situada em um subtítulo através do relato de uma militante feminista próxima as vítimas, que faz uma reinterpretação das palavras das adolescentes, afirmando que elas "quase desistiram". Pela forma do enunciado, o portal dá margens para seus destinatários duvidarem da declaração, sob o argumento de não ter sido das vitimas, mas uma opinião do portal, composta para este episódio.

\section{Conclusão}

A partir da análise acima, concluímos que o G1 Bahia, através de seus posicionamentos, procurou blindar-se em boa parte da cobertura através das declarações da justiça e da medicina, emitindo sua posição apenas quando o judiciário decretou a comprovação clínica do estupro, o que foi incorreto do ponto de vista jurídico já que o crime de estupro desde 2009, com a reforma do Código Penal, é considerado para além da conjunção carnal.

A manutenção de um distanciamento da sociedade o aproximou da estratégia de porta-voz do caso, isento de opiniões próprias e autorizado pela justiça para "dar a notícia correta". Este movimento levou o portal para uma postura informativa, como um "boletim de notícias" que dialogava com qualquer público, desde os mais 


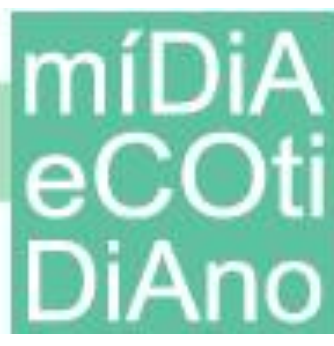

desinformados sobre o caso e a banda até os/as fãs do grupo e ativistas pelo combate à violência contra mulher.

A construção de sentido sobre a violência sexual variou com o tempo do caso. As primeiras coberturas enfatizaram a suposição de crime (se havia acontecido ou não o estupro) e o contexto ocorrido (após um show da banda). O sentido de dúvida do crime foi disseminado no portal, uma vez que muitas enunciações questionavam implicitamente a prisão dos acusados através de afirmações que tratavam do fato como um "suposto estupro", "acusação de estupro" etc.

A exploração do momento do crime - no ônibus da banda depois do show construiu o sentido de co-responsabilidade das vítimas sobre o caso, e o portal afirmou nas entrelinhas a "imprudência" das adolescentes em procurar os músicos depois do show, não levando em consideração a liberdade de ir e vir das adolescentes, tampouco a responsabilidade da banda e de seu segurança - também policial militar - em preservar a integridade das fãs.

Apenas a partir da comprovação de violência em seu aspecto carnal - através dos laudos - que o portal deu início à construção do sentido de crime ao caso. Contudo, a constante humanização dos acusados e a sustentação da dúvida sobre a violência até o fim da cobertura contribuíram para que o sentido hediondo do crime não fosse destaque na maioria dos títulos, com ressalva para os poucos momentos nos quais a palavra foi franqueada aos movimentos sociais, parlamentares e vítimas.

Esse trabalho de monitoramento e análise de acontecimentos noticiosos serve para explicitar o lugar de fala dos veículos de comunicação no interior da sociedade e como tais veículos de comunicação constroem sua voz a partir da articulação das várias vozes que edificam as notícias. A partir da análise do posicionamento discursivo de veículos de comunicação, o CCDC - Centro de Comunicação, Democracia e Cidadania -, da Faculdade de Comunicação da UFBA, conduz sua ação, de um lado, junto aos movimentos sociais e, de outro, junto às autoridades públicas proporcionando uma leitura crítica dos meios de comunicação e, por conseguinte, uma mobilização em prol da cidadania, como foi o caso a partir da cobertura do acontecimento "New Hit". 


\section{míDiA
eCOti
DiAno}

\section{Referências bibliográficas:}

AZEREDO, Maria Amélia. GUERRA, Viviane. Pele de asno não é só estória...um estudo sobre a vitimização sexual de crianças e adolescentes em família. São Paulo: Editora Roca, 1988.

BARTHES, Roland, La chamber Claire - note sur la photographie, Paris, Gallimard / Seuil, 1980

BENVENISTE, Émile. Problemas de linguística geral II. Campinas: Pontes, 1989.

BROWNMILLER, Susan. Against Our Will: Men, Women, and Rape. EUA, 1975

CHARAUDEAU, Patrick. Discurso das Mídias. 1 ed. - São Paulo: Contexto, 2009.

DUBOIS, Jean, "Enoncé et énonciation", in Langages, n 13, Paris, 1969, p. 100-110.

Estatuto da Criança e do Adolescente. Lei n 8.069. Brasil 1990.

FERREIRA, M. Giovandro. Contribuições da análise do discurso ao estudo de jornalismo. Rio de janeiro, XI COMPOS, 2002. http://www.compos.org.br/pagina.php?menu=8\&mmenu=0\&fcodigo=707. Em 01/04/13.

FERREIRA, G. M. ; SAMPAIO, A. de O. ; MAGALHÃES, D. R. ; CARIBÉ, P. A. . A construção da violência na televisão da Bahia - um estudo dos programas Se Liga Boção e Na Mira. Salvador: EDUFBA, 2011.

LAGARDE, Marcela, RUSSELL, Diana e HAMES, Harmes (orgs.). Feminicidio: una perspectiva global, México, Comisión Especial para Conocer y Dar Seguimiento a las Investigaciones Relacionadas con los Feminicidios en la República Mexicana y a la Procuración de Justicia Vinculada, 2006.

El feminicidio, delito contra la humanidad", Feminicidio, justicia y derecho, México, Comisión Especial para Conocer y Dar Seguimiento a las Investigaciones Relacionadas con los Feminicidios en la República Mexicana y a la Procuración de Justicia Vinculada, 2005

MAINGUENEAU, Dominique. Análise de textos de comunicação. São Paulo: 90 Cortez, 2002.

Novas tendências em análise do discurso. Campinas: Pontes, 1989. 198p. Tradução de: Nouvelles tendances en analyse du discours. Paris: Hachette, 1987. 
MONÁRREZ, Julia, Trama de una injusticia: Feminicidio sexual sistémico em Ciudad Juárez, México, Colegio de la Frontera Norte, 2009.

RUSSELL, Diana E. H. e Van de Ven, Nicole. Crimes against Women: The Proceedings of the International Tribunal, San Francisco, California, Frog in the Well, 1982.

SAFFIOTI, Heleieth. Contribuições feministas para o estudo da violência de gênero. Cadernos Pagu, n. 16, p. 115-136, 2001.

Feministas, n. especial, 1994, p. 443 - 461.

VAN DIJK. La Noticia como discurso. Barcelona: Paidós, 1990.

VERÓN, Eliseo. Fragmentos de um tecido. São Leopoldo: Editora Unisinos, 2004.

WAISELFISZ, Julio J. Mapa da Violência 2012. Atualização: Homicídio de Mulheres no Brasil. FLACSO Brasil, 2012. Disponível em: http://www.mapadaviolencia.org.br <acesso em novembro de 2013>.

WEINRICH, Harald, Le temps, Paris, Seuil, 1973. 